\title{
Synthesis and antiviral evaluation of 2-amino-1,6-dihydro-6-oxo-9- [4-bis(hydroxymethyl) -2-cyclopenten-1-yl]-9H-purine: an analog of the anti-HIV compound Carbovir
}

\author{
Pawan K. Sharma and Vasu Nair* \\ Department of Chemistry, the University of Iowa, Iowa City, Iowa 52242, USA \\ E-mail: vasu-nair@uiowa.edu
}

(received 05 May 00; accepted 13 Feb 00; published on the web 21 Feb 00)

\begin{abstract}
A novel carbovir analog, ( \pm )-2-amino-1,6-dihydro-6-oxo-9-[4-bis(hydroxymethyl)-2cyclopenten-1-yl]-9H-purine, was synthesized starting from the $\gamma$-lactam, 2-azabicyclo [2.2.1]hept-5-en-3-one (7). The key intermediate, 1-acetamido-4-bis(hydroxymethyl)cyclopent2-ene (10), was prepared by the Pfitzner-Moffatt oxidation of the hydroxymethyl group of $\mathbf{8}$, aldol condensation of the resulting aldehyde, followed by a Cannizzaro reaction. The guanine base was constructed on the amino group of 10. The structures of the target molecule and the intermediates were confirmed by NMR, UV and HRMS data. Anti-HIV evaluation results are reported.
\end{abstract}

Keywords: Anti HIV, carbovir, Pfitzner-Moffatt oxidation, Cannizzaro reaction

\section{Introduction}

Modified analogs of natural nucleosides have been widely studied as potential antitumor, antiviral and fungicidal agents. ${ }^{1,2}$ Search for nucleoside analogs which function as nontoxic, selective inhibitors of polymerases and other enzymes for the control of viral diseases and cancer has been the subject of intense research. ${ }^{3-6}$ However, as some of these nucleosides also undergo enzymatic degradations, a number of modifications have been carried out on both the sugar portion and the heterocycle to circumvent or to retard these deactivating processes. Nucleoside analogs that are good substrates for cellular kinases, but are resistant to other host enzymes such as phosphorylases (glycosidic bond cleavage) and deaminases (hydrolytic deamination) are essential for the development of useful therapeutic antiviral agents.

One important discovery in this area has been the replacement of the oxygen in the sugar portion of the nucleoside with a methylene unit, which results in carbocyclic nucleoside analogs which are highly resistant to phosphorylases. ${ }^{7}$ Carbocyclic analogs of nucleosides (CANs) have recently become the object of increased interest owing to their demonstrated antineoplastic ${ }^{6}$ and 
antiviral $^{8}$ properties. While the carbocyclic analog of adenosine was first described by Shealy and Clayton ${ }^{9}$ in 1966, it was the discovery that the natural carbocyclic nucleosides, aristeromycin (1) ${ }^{10}$ and neplanocin A (2), ${ }^{11}$ display antibiotic and antitumor activity that sparked the search for other CANs with biological activity (Figure 1). Among the antiviral CANs discovered in the search for agents active against human immunodeficiency virus (HIV), the most promising are carbovir (3), ${ }^{12}$ the structurally related abacavir (4) ${ }^{13}$ as well as BCA (5). ${ }^{14}$

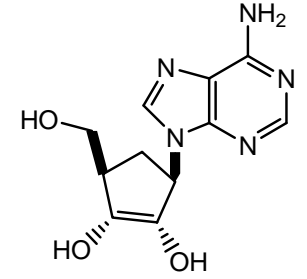

1 (aristeromycin)

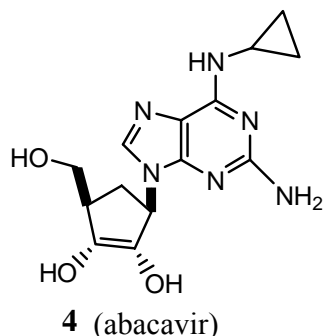

4 (abacavir)

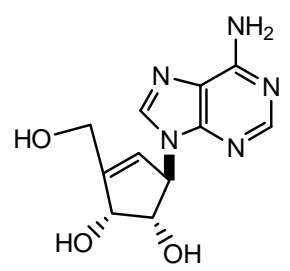

2 neplanocin A

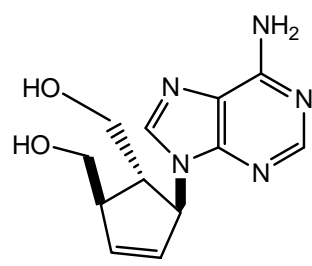

5 (-) BCA

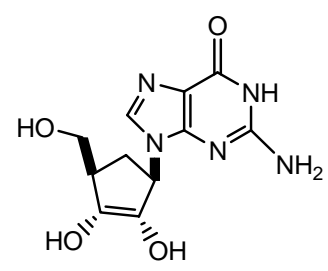

3 (Carbovir)

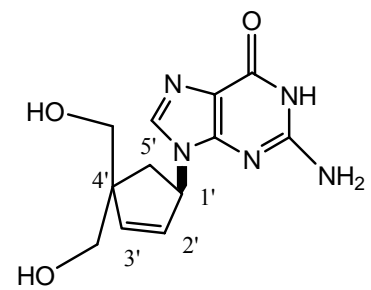

6

Figure 1

Although promising new antiviral agents have been discovered, their long-term usefulness is somewhat limited by their toxicities ${ }^{15}$ and development of resistant strains on prolonged clinical use. Therefore, the search for new inhibitors of HIV continues. Our interest in the title compound 6 was stimulated by the observation of the in vitro anti-HIV activity of $4^{\prime}$-substituted nucleosides. ${ }^{16,17}$ For example, $4^{\prime}$-hydroxymethylthymidine exhibits good activity against HIV1. ${ }^{17}$ In addition, compound 5 also shows good activity against HIV-1 in MT-4 cells (IC50 $0.20 \mu \mathrm{g} / \mathrm{mL}) .{ }^{14}$ However, to the best of our knowledge, there is no report on the synthesis and anti-HIV evaluation of $4^{\prime}$-substituted CANs. We describe herein the synthesis and antiviral evaluation of a 4' -substituted carbovir analog, 2-amino-1,6-dihydro-6-oxo-9-[4bis(hydroxymethyl)-2-cyclopenten-1-yl]-9H-purine 6).

\section{Results and Discussion}

The route adopted for the synthesis of 6 utilizes the $\gamma$-lactam, 2-azabicyclo[2.2.1]hept-5-en-3one (7), which is commercially available (Scheme 1). Hydrolysis of the lactam 7 with aqueous hydrochloric acid followed by esterification, acetylation and reduction by calcium borohydride provided the alcohol 8. ${ }^{18}$ We thought of introducing the hydroxymethyl group at the $4^{\prime}$-position of the cyclopentene ring through the aldehyde 9, using in tandem, an aldol and a Cannizzaro 
reaction. ${ }^{19}$ Oxidation of the hydroxymethyl group of 8 under Swern conditions ${ }^{20}$ resulted in a mixture of products which could not be identified. The oxidation of alcohol 8 using Moffatt conditions (DCC, DMSO, DCAA) was then investigated with good results. ${ }^{21,22}$ The resulting aldehyde 9, without isolation, on aldol condensation with formaldehyde, followed by a Cannizzaro reaction provided the required 1-acetamido-4-bis(hydroxymethyl)cyclopent-2-ene (10) in 51\% overall yield. Bishydroxymethyl compound 10 was deacetylated under acidic conditions and the resulting amino alcohol was coupled with 2-amino-4,6-dichloropyrimidine in the presence of diisopropylethylamine to give $\mathbf{1 1}$ in 50\% overall yield.
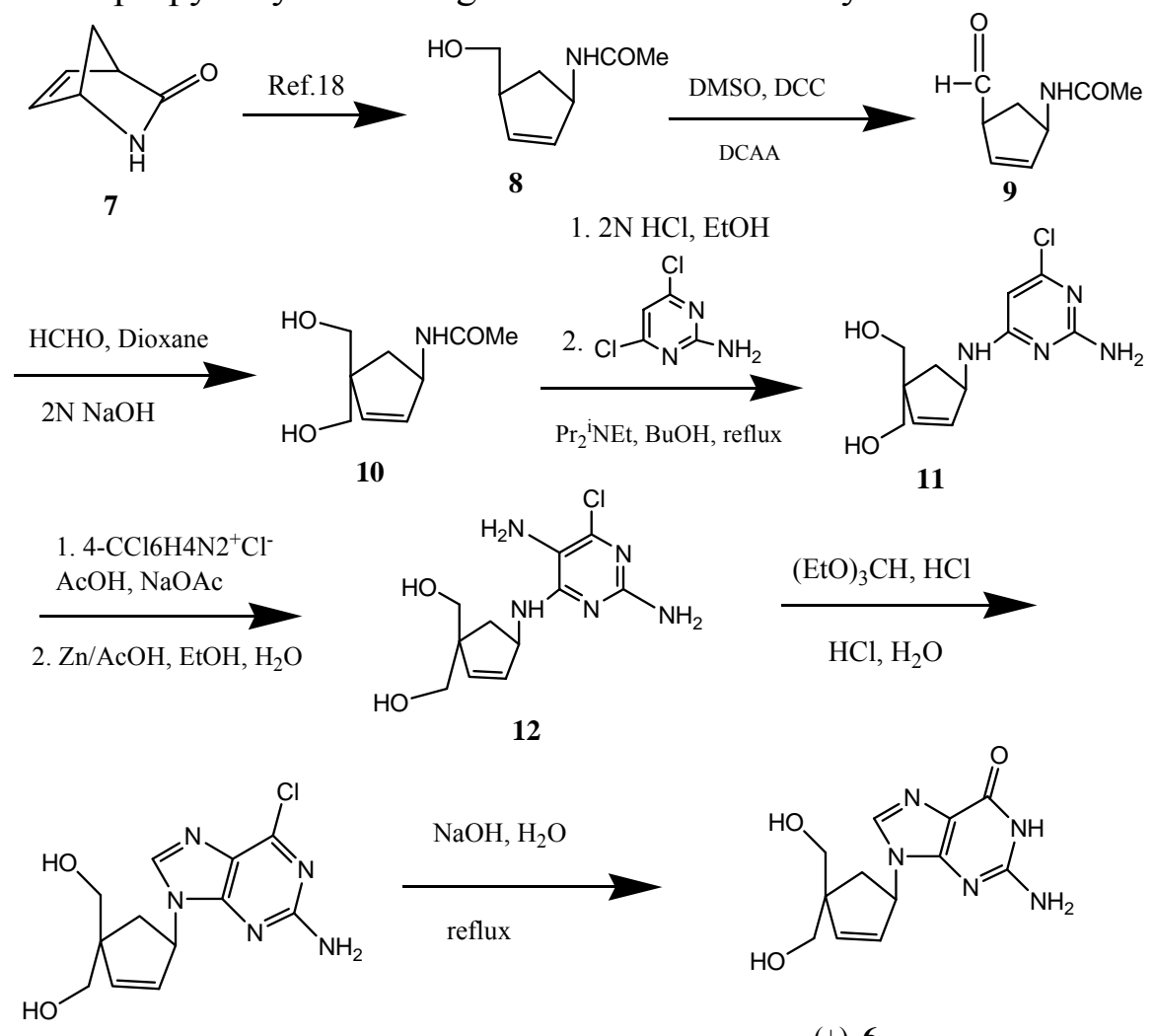

13

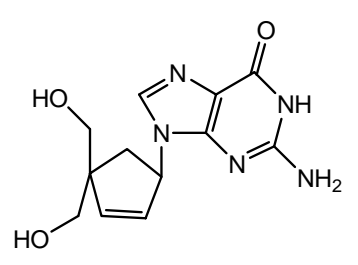

(土) 6

\section{Scheme 1}

Diazotization of the diamine $\mathbf{1 1}$ using 4-chlorophenyldiazonium chloride followed by reduction of the yellow diazo compound with zinc-acetic acid afforded 12. Cyclization of $\mathbf{1 2}$ with triethyl orthoformate under acidic conditions and subsequent treatment of the resulting compound 13 with aqueous sodium hydroxide under reflux gave the target compound ( \pm ) 6 . Interestingly, compound $\mathbf{1 3}$ is a very poor substrate for mammalian adenosine deaminase. Finally, compound $\mathbf{6}$ did not show significant anti-HIV activity in vitro in infected CEM-SS cells $($ IC50 $>200 \mu \mathrm{M}$ ).

\section{Experimental Section}

General Procedures. Melting points reported are uncorrected and were determined on a Thomas 
Hoover apparatus fitted with a microscope. NMR spectra were recorded on Bruker AC-300 pulse Fourier transform spectrometer. Mass spectra were determined on a VG ZAB-HF instrument. UV spectra were recorded on a Cary 3 UV spectrometer. Preparative layer chromatography used plates prepared with E. Merck PF254 silica gel. Flash chromatography was carried out on columns packed with 240-400 mesh silica gel.

1-Acetamido-4-bis(hydroxymethyl)cyclopent-2-ene (10). A solution of $\mathbf{8}^{18}$ (880 $\mathrm{mg}$, $5.68 \mathrm{mmol})$, dicyclohexylcarbodiimide $(4.69 \mathrm{~g}, 22.71 \mathrm{mmol})$ and dichloroacetic acid (366 mg, $2.84 \mathrm{mmol})$ in DMSO $(50 \mathrm{~mL})$ was stirred under nitrogen at room temperature for $48 \mathrm{~h}$. Solvent was evaporated under reduced pressure and the residue, presumably containing $\mathbf{9}$, was suspended in petroleum ether $(400 \mathrm{~mL})$ and extracted with water $(3 \times 150 \mathrm{~mL})$. The water later was filtered and concentrated under reduced pressure. $37 \%$ solution of formaldehyde $(1.84 \mathrm{~mL}, 22.71 \mathrm{mmol})$ and $2 \mathrm{~N}$ sodium hydroxide $(11.36 \mathrm{~mL}, 22.71 \mathrm{mmol})$ were added to a solution of the above residue in 1,4-dioxane $(50 \mathrm{~mL})$. The resulting mixture was stirred at room temperature for $46 \mathrm{~h}$. neutralized with $1 \mathrm{~N}$ hydrochloric acid and the solvents were evaporated under reduced pressure. The residue was purified on silica gel $\left(15 \% \mathrm{MeOH}-\mathrm{CHCl}_{3}\right)$ to give $\mathbf{1 0}$ as a colorless viscous liquid (540 mg, 51.4\%). ${ }^{1} \mathrm{H}$ NMR ( $\left.\mathrm{CD}_{3} \mathrm{OD}\right): \delta 5.93-5.85(\mathrm{~m}, 2 \mathrm{H}, 2-\mathrm{H}$ and $3-\mathrm{H}), 4.83(\mathrm{~m}, 1 \mathrm{H}, 1-$ $H$ ), 3.60-3.40 (m, 4H, $\left.2 \times \mathrm{CH}_{2} \mathrm{OH}\right), 2.20-2.10(\mathrm{dd}, 1 \mathrm{H}, 5-\mathrm{H}), 1.91\left(\mathrm{~s}, 3 \mathrm{H}, \mathrm{CH}_{3}\right), 1.48-1.38(\mathrm{dd}$, $\left.1 \mathrm{H}, 5^{\prime}-\mathrm{H}\right) ;{ }^{13} \mathrm{C}$ NMR $\left(\mathrm{CD}_{3} \mathrm{OD}\right): \delta 170.5(\mathrm{CON}), 136.1$ and 132.1 (2-C and 3-C), 65.11 and 65.08 $\left(2 \times \mathrm{CH}_{2} \mathrm{O}\right), 56.0(1-\mathrm{C}), 54.3(4-\mathrm{C}), 36.2(5-\mathrm{C}), 20.9\left(\mathrm{CH}_{3}\right)$; HRMS (FAB) calculated for $\mathrm{C}_{9} \mathrm{H}_{16} \mathrm{NO}_{3}:(\mathrm{M}+\mathrm{H})+186.1131$, found 186.1122 .

4-Bis(hydroxymethyl)-1-[(2-amino-6-chloropyrimidin-4-yl)amino]cyclopent-2-ene (11). Bis hydroxymethyl compound $\mathbf{1 0}(575 \mathrm{mg}, 3.11 \mathrm{mmol})$ was refluxed under nitrogen in a mixture of ethanol $(11 \mathrm{~mL})$ and $2 \mathrm{~N}$ hydrochloric acid $(16.1 \mathrm{~mL})$ for $70 \mathrm{~h}$. The solvent was removed under reduced pressure. Butanol (17 mL), 2-amino-4,6-dichloropyrimidine (1.02 g, $6.22 \mathrm{mmol})$ and diisopropylethylamine $(7.73 \mathrm{~mL})$ were added and the mixture refluxed under nitrogen for $28 \mathrm{~h}$, then poured into water $(21 \mathrm{~mL})$ and extracted with dichloromethane $(4 \times 80 \mathrm{~mL})$. The combined organic layers were dried (MgSO4) and concentrated. Column chromatography $(11 \% \mathrm{MeOH}-$ $\mathrm{CHCl}_{3}$ ) gave compound $11(425 \mathrm{mg}, 50.6 \%)$ as a white foam, mp 108-110 $\left.{ }^{\circ} \mathrm{C} . \%\right) .{ }^{1} \mathrm{H}$ NMR $\left(\mathrm{CD}_{3} \mathrm{OD}\right): \delta 5.80-5.65\left(\mathrm{~m}, 3 \mathrm{H}, 2^{\prime}-\mathrm{H}, 3^{\prime}-\mathrm{H}\right.$ and pyrimidine-5- $\left.H\right), 4.78\left(\mathrm{~m}, 1 \mathrm{H}, 1^{\prime}-\mathrm{H}\right), 3.54-3.38$ (m, 4H, $\left.2 \times \mathrm{CH}_{2} \mathrm{OH}\right), 2.24-2.08\left(\mathrm{dd}, 1 \mathrm{H}, 5^{\prime}-\mathrm{H}\right), 1.48-1.33\left(\mathrm{dd}, 1 \mathrm{H}, 5^{\prime \prime}-\mathrm{H}\right) ;{ }^{13} \mathrm{C} \mathrm{NMR}\left(\mathrm{CD}_{3} \mathrm{OD}\right)$ : $\delta 163.0$ (2-C), 162.3 (4-C), 135.6 and 132.3 (2' $-\mathrm{C}$ and $3^{\prime}$-C), 108.7 (6-C), 107.4 (5-C), 65.03 (2 $\left.\times \mathrm{CH}_{2} \mathrm{O}\right), 55.82$ and $55.80\left(4^{\prime}-\mathrm{C}\right.$ and $\left.1^{\prime}-\mathrm{C}\right), 36.32\left(5^{\prime}-\mathrm{C}\right)$.

4-Bis(hydroxymethyl)-1-[(2,5-diamino-6-chloropyrimidin-4-yl)amino]cyclopent-2-ene (12). A solution of sodium nitrite $(129 \mathrm{mg}, 1.85 \mathrm{mmol})$ in water $(1.5 \mathrm{~mL})$ was added dropwise to a solution of 4-chloroaniline $(217 \mathrm{mg}, 1.70 \mathrm{mmol})$ in $2.7 \mathrm{~N}$ hydrochloric acid $(3.7 \mathrm{~mL})$ at $9{ }^{\circ} \mathrm{C}$. The resultant solution was added quickly dropwise to a solution of pyrimidine 11 (400 $\mathrm{mg}$, $1.48 \mathrm{mmol})$ and sodium acetate $(1.78 \mathrm{~g})$ in water $(7.4 \mathrm{~mL})$ and glacial acetic acid $(7.4 \mathrm{~mL})$ at room temperature. The mixture was stirred vigorously for $44 \mathrm{~h}$ and the bright orange solid was filtered, washed with water until neutral and crystallized from ethyl acetate to afford 4- 
bis(hydroxymethyl)-1-[\{2-amino-6-chloro-5-[(4-chlorophenyl)azo]-4-pyrimidinyl $\}$ amino]cyclopent-2-ene (431 mg, 71.3\%) as a bright yellow solid, mp 252.8-253.4 ${ }^{\circ} \mathrm{C}$ (decomp.). ${ }^{1} \mathrm{H}$ NMR (CD $\left.{ }_{3} \mathrm{OD}\right): \delta 10.41(\mathrm{~d}, \mathrm{NH}), 7.8-7.7$ (d, 2H, Ar-H), 7.48-7.38 (d, 2H, Ar-H), 5.96-5.84 (m, $2 \mathrm{H}, 2^{\prime}-\mathrm{H}$ and $\left.3^{\prime}-\mathrm{H}\right), 5.46-5.30\left(\mathrm{~m}, 1 \mathrm{H}, 1^{\prime}-\mathrm{H}\right), 3.64-3.48\left(\mathrm{~m}, 4 \mathrm{H}, 2 \times \mathrm{CH}_{2} \mathrm{OH}\right), 2.40-2.33(\mathrm{dd}$, $\left.1 \mathrm{H}, 5^{\prime}-H\right), 1.75-1.58\left(\mathrm{dd}, 1 \mathrm{H}, 5^{\prime \prime}-H\right)$.

This azo compound (430 mg, $1.051 \mathrm{mmol})$, zinc dust (740 $\mathrm{mg}, 11.32 \mathrm{mmol}$ ), glacial acetic acid $(0.36 \mathrm{~mL})$, ethanol $(17.5 \mathrm{~mL})$ and water $(17.5 \mathrm{~mL})$ was refluxed under nitrogen for $3 \mathrm{~h}$. The mixture was filtered and concentrated, azeotroping several times with ethanol. The residue was dissolved in methanol and absorbed onto silica. Column chromatography $\left(10 \% \mathrm{MeOH}-\mathrm{CHCl}_{3}\right)$

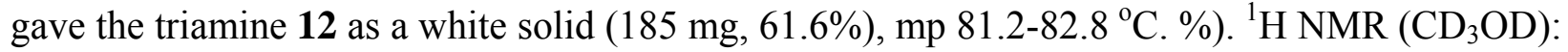
$\delta$ 6.35(d, NH), 5.85-5.75 (m, 2H, $2^{\prime}-H$ and $\left.3^{\prime}-H\right), 5.15\left(\mathrm{~m}, 1 \mathrm{H}, 1^{\prime}-H\right), 3.62-3.49(\mathrm{~m}, 4 \mathrm{H}, 2 \times$ $\left.\mathrm{CH}_{2} \mathrm{OH}\right), 2.23\left(\mathrm{dd}, 1 \mathrm{H}, 5^{\prime}-\mathrm{H}\right), 1.53\left(\mathrm{dd}, 1 \mathrm{H}, 5^{\prime \prime}-\mathrm{H}\right)$; HRMS (FAB) calculated for $\mathrm{C}_{11} \mathrm{H}_{17} \mathrm{ClN}_{5} \mathrm{O}_{2}$ : $(\mathrm{M}+\mathrm{H})+286.1072$, found 286.1065 .

2-Amino-6-chloro-9-[4-bis(hydroxymethyl)-2-cyclopenten-1-yl)]-9H-purine (13). Pyrimidine 12 (177 $\mathrm{mg}, 0.62 \mathrm{mmol})$ was added to conc. hydrochloric acid $(0.15 \mathrm{~mL})$ in freshly distilled triethyl orthoformate $(3.8 \mathrm{~mL})$ and the mixture stirred for $31 \mathrm{~h}$ at room temperature. The mixture was concentrated and the resultant solid stirred in $0.5 \mathrm{~N}$ hydrochloric acid $(6 \mathrm{~mL})$ for $1 \mathrm{~h}$ when sufficient $1 \mathrm{~N}$ sodium hydroxide solution was added to adjust the mixture to $\mathrm{pH} 8$. The mixture was concentrated, dissolved in methanol and absorbed onto silica. Column chromatography $\left(12 \% \mathrm{MeOH}_{-} \mathrm{CHCl}_{3}\right)$ gave $13(157 \mathrm{mg}, 85.7 \%)$ as a white foam-like solid, $\mathrm{mp} 179.1-179.5{ }^{\circ} \mathrm{C}$. ${ }^{1} \mathrm{H}$ NMR $\left(\mathrm{CD}_{3} \mathrm{OD}\right): \delta 8.08(\mathrm{~s}, 1 \mathrm{H}, 8-H), 6.10-5.90\left(\mathrm{~m}, 2 \mathrm{H}, 2^{\prime}-H\right.$ and $\left.3^{\prime}-H\right), 5.62\left(\mathrm{~m}, 1 \mathrm{H}, 1^{\prime}-H\right)$, 3.65-3.45 (m, 4H, $\left.2 \times \mathrm{CH}_{2} \mathrm{OH}\right), 2.47\left(\mathrm{dd}, 1 \mathrm{H}, 5^{\prime}-\mathrm{H}\right), 1.89\left(\mathrm{dd}, 1 \mathrm{H}, 5^{\prime \prime}-\mathrm{H}\right) ;{ }^{13} \mathrm{C} \mathrm{NMR}\left(\mathrm{CD}_{3} \mathrm{OD}\right): \delta$ 159.6 (6-C), 152.9 (2-C), 149.5 (4-C), 141.0 (5-C), 140.0 (8-C), 129.3 (2' -C), 123.2 (3'-C), 65.2 and $64.5\left(2 \times \mathrm{CH}_{2} \mathrm{O}\right), 59.36\left(1^{\prime}-\mathrm{C}\right), 57.3\left(4^{\prime}-\mathrm{C}\right), 36.3\left(5^{\prime}-\mathrm{C}\right)$.

\section{2-Amino-1,6-dihydro-6-oxo-9-[4-bis(hydroxymethyl)-2-cyclopenten-1-yl]-9H-purine (6).}

Chloropurine $13(146 \mathrm{mg}, 0.49 \mathrm{mmol})$ was gently refluxed under nitrogen in $0.33 \mathrm{~N}$ sodium hydroxide $(6.8 \mathrm{~mL})$ for $5 \mathrm{~h}$. The mixture was concentrated in vacuo, dissolved in methanol and absorbed onto silica. Column chromatography $\left(30 \% \mathrm{MeOH}_{-} \mathrm{CHCl}_{3}\right)$ gave 6 ontaminated with silica. Further purification by ion-exchange chromatography using DOWEX $50 \mathrm{~W} \times 8$-200 ion exchange resin gave 6 (90 mg, 65.8\%) as white solid which was crystallized from methanol, $\mathrm{mp}$ 273.8-274.1 ${ }^{\circ} \mathrm{C}$. UV $(0.1 \mathrm{~N} \mathrm{HCl}) \lambda \max =253$ and $278 \mathrm{~nm}(\varepsilon=14700$ and 11300$),{ }^{1} \mathrm{H}$ NMR (DMSO-d6): $\delta 10.32$ (brs, 1H, NH), $7.60(\mathrm{~s}, 1 \mathrm{H}, 8 \mathrm{H}), 6.42(\mathrm{~s}, 2 \mathrm{H}, \mathrm{NH}$ ) , 5.94-5.81 (m, 2H, 2' -H and $\left.3^{\prime}-\mathrm{H}\right), 5.39\left(\mathrm{~m}, 1 \mathrm{H}, 1^{\prime}-\mathrm{H}\right), 4.68-4.62(\mathrm{~m}, 2 \mathrm{H}, \mathrm{OH}), 3.49-3.28\left(\mathrm{~m}, 4 \mathrm{H}, 2 \times \mathrm{CH}_{2} \mathrm{OH}\right), 2.30-$ $2.25\left(\mathrm{dd}, 1 \mathrm{H}, 5^{\prime}-H\right), 1.70-1.60\left(\mathrm{dd}, 1 \mathrm{H}, 5^{\prime \prime}-H\right) ;{ }^{13} \mathrm{C}$ NMR (DMSO-d6): $\delta 156.7,153.3,150.7$, 141.2, 139.2, 136.0, 131.0, 116.5, 116.4, 64.87, 64.55, 57.34; HRMS (FAB) calculated for $\mathrm{C}_{12} \mathrm{H}_{16} \mathrm{~N}_{5} \mathrm{O}_{3}:(\mathrm{M}+\mathrm{H})+278.1254$, found 278.1248 .

\section{Acknowledgments}

We are grateful to Dr. Lynn Teesch and Ms. Diane Herschberger for the HRMS data. This 
research work was supported by the National Institutes of Health (NIAID). We thank the NCI for the anti-HIV evaluations.

\section{References}

1. Chemistry of Nucleosides and Nucleotides, Townsend, L. B., Ed.; Plenum Press: New York, 1988, 1991, 1994, Vols. 1, 2, 3.

2. Nucleosides and Nucleotides as Antiviral and Antitumor Agents, Chu, C. K.; Baker, D. C., Eds.; Plenum Press: New York, 1991.

3. Borthwick, A.D.; Biggadike, K. Tetrahedron 1992, 48, 571.

4. Argofoglio, L.; Suhas, E.; Farese, A.; Condom, R.; Challand, S. R.; Earl, R. A.; Guedj, R. Tetrahedron 1994, 50, 10611.

5. Nair, V.; Jahnke, T. S. Antimicrob. Agents Chemother. 1995, 39, 1017, and references therein.

6. (a) Marquez, V.; Lim, M. Med. Res. Rev. 1986, 6, 1. (b) Roberts, S.; Biggadike, K.; Borthwick, A.; Kirk, B. E. Topics in Medicinal Chemistry, Royal Society of Chemistry, 1988, 172.

7. Desgranges, C.; Razaka, G.; Rabaud, M.; Bricaud, H.; Balzarini, J.; De Clercq, E. Biochem. Pharmacol. 1983, 32, 3583.

8. Maruyama, T.; Hanai, Y.; Sato, Y.; Snoeck, T.; Andrei, G.; Hosoya, M.; Balzarini, J.; De Clercq, E. Chem. Pharm. Bull. 1993, 41, 516.

9. (a) Shealy, Y. F.; Clayton, J. D. J. Am. Chem. Soc. 1966, 88, 3885. (b) Shealy, Y. F.; Clayton, J. D. J. Am. Chem. Soc. 1969, 91, 3075. (c) Shealy, Y. F.; Clayton, J. D. J. Pharm. Sci. 1973, 62, 1432.

10. Kusaka, T.; Yamamoto, H.; Shibata, M.; Muroi, M.; Kishi, T.; Mizuno, K. J. Antibiot. 1968, 21, 255.

11. Yaginuma, S.; Muto, N.; Tsujino, M.; Sudate, Y.; Hayashi, M.; Otani, M. J. Antibiot. 1981, 34, 359.

12. Vince, R.; Hua, M. J. Med. Chem. 1990, 33, 17.

13. "Therapeutic Nucleosides" Daluge, S. M. U.S. Patent 1991, 5,034,394.

14. Katagiri, N.; Nomura, M.; Sato, H.; Kaneko, C.; Yusa, K.; Tsuruo, T. J. Med. Chem. 1992, 35, 1882.

15. De Clercq, E. J. Med. Chem. 1995, 38, 2491, and references therein.

16. Maag, H.; Rydzewski, R. M.; McRoberts, M. J.; Crawford-Ruth, D.; Verheyden, J. P.H.; Prisbe, E. J. J. Med. Chem. 1992, 35, 1440.

17. O-Yang, C.; Kurz, W.; Eugui, E. M.; McRoberts, M. J.; Verheyden, J. P. H.; Kurz, L. J.; Walker, K. A. M. Tetrahedron Lett. 1992, 33, 41.

18. Evans, C. T.; Roberts, S. M.; Shoberu, K. A.; Sutherland, A. G. $\quad$ J. Chem. Soc., Perkin Trans. 1 $1992,589$.

19. O-Yang, C.; Wu, H.Y.; Fraser-Smith, E. B.; Walker, K. A. M. Tetrahedron Lett.1992, 33, 37.

20. Mancuso, A. J.; Swern, D. Synthesis 1981, 165.

21. Jones, G. H.; Taniguchi, M.; Tegg, D.; Moffatt, J. G. J. Org. Chem. 1979, 44, 1309.

22. Zintek, L. B.; Jeon, G. S.; Nair, V. Heterocycles 1994, 37, 1853. 